\title{
A 10-year climatology of vertical properties of most active convective clouds over the Indian regions using TRMM PR
}

\author{
Shailendra Kumar ${ }^{1}$ \\ Received: 6 February 2014 / Accepted: 8 September 2015 /Published online: 28 September 2015 \\ (C) Springer-Verlag Wien 2015
}

\begin{abstract}
Vertical distribution of hydrometeors in the most intense convective clouds over the Indian region during the summer monsoon season (JJAS) is described for ten climatologically important areas. Tropical Rainfall Measuring Mission Precipitation Radar (TRMM PR) 3D radar reflectivity data is used in the present study for 10 years (2001-2010). The study constructs a convective cloud cell based on reflectivity thresholds, known as most intense convective cloud. The cloud cells are formed by taking the maximum reflectivity (Ze) at each altitude in the convective area with at least one radar pixel containing reflectivity of $40 \mathrm{dBZ}$ or more. TRMM 2 A23 data was used to eliminate the stratiform clouds from our analyses. The Vertical structure of convective clouds were studied over the east and west coast of India, and observation shows that the east coast consists of a higher frequency of convective clouds with high reflectivity values in average vertical profiles. It is observed that over the northeastern parts of the Indian subcontinent, $\sim 30 \%$ of convective cells extend beyond $15-\mathrm{km}$ height whereas it is only $\sim 4 \%$ over the central Bay of Bengal. Over the Western Ghats, $\sim 13 \%$ of the cells have their tops below the freezing level, i.e. warm clouds do give heavy rain here. The regional differences in the vertical profile are high between the 5- and 12-km altitude. Most intense convective cells (MICCs) with a cloud top height more than 10 and $15 \mathrm{~km}$ show different characteristics, and the
\end{abstract}

Electronic supplementary material The online version of this article (doi:10.1007/s00704-015-1641-5) contains supplementary material, which is available to authorized users.

Shailendra Kumar

shailendra@caos.iisc.ernet.in

1 Centre for Atmospheric and Oceanic Sciences, Indian Institute of Science, Bangalore 560012, India
Western Ghats shows the most intense average vertical profile. Above $12 \mathrm{~km}$, the western coast shows increased reflectivity value. Convective intensity is higher over the land-dominated areas for the cloud cells and decreases when we restrict the cloud cells to a certain altitude.

\section{Introduction}

The tropical cumulonimbus clouds $(\mathrm{Cb})$, which are also classified as 'hot towers' (Riehl 1979), play an important role in Earth's water and energy cycle and are responsible for atmospheric circulation (Charney 1969; Holton 2004). Maximum contribution to vertical transportation of energy comes from Cb clouds (Riehl 1979) and also feed hydrometeors to stratiform regions of mesoscale convective systems (MCSs, e.g. Houze 1989). The Tropical Rainfall Measuring Mission Precipitation Radar (TRMM PR, henceforth) provides the volumetric data of reflectivity (in dBZ) since its launch date (i.e. December 1997), and it consists of large time series data for understanding precipitating cloud systems (Kummerow et al. 1998, 2000).

TRMM PR is used with other on-board sensors, such as the TRMM microwave imager (TMI), to study the properties of precipitating cloud systems. 'TRMM precipitation features (PFs)' contain the data from different sensors mounted on the TRMM satellite (Nesbitt et al. 2000). These PFs are used for extracting the properties of tropical cloud systems (Nesbitt et al. 2006; Liu et al. 2008; Liu et al. 2012; Xu and Zipser 2012). Deep convective clouds export water from the troposphere to the stratosphere (e.g. Simpson et al. 1998) and 5 \% of clouds are involved in this process (Alcala and Dessler 2002). Inter-comparison between continental and oceanic cloud system is done by using the TRMM data (Nesbitt et al. 2000; Toracinta et al. 2002). Generally, continental areas exhibit a higher fraction of deep convective clouds and higher 
reflectivity (Ze) values compared to oceanic cloud systems. Central Africa, Argentina and India (land areas) show deeper and horizontally more extensive PFs compared to oceans (Liu et al. 2007). Geographic locations strongly affect the properties of deep convective clouds, but warm precipitation does not show regional differences in size and intensity features (Liu et al. 2008). Warm clouds contribute 20 and $7.5 \%$ to the total precipitation over tropical oceans and land (Liu et al. 2008), respectively. Xu and Zipser (2012) reveal that a storm with $\mathrm{Ze} \geq 40 \mathrm{dBZ}$ above $6 \mathrm{~km}$ is four times higher over land $(40 \%)$ compared to the ocean $(10 \%)$. Other significant properties of precipitating clouds such as diurnal variation (e.g. Takayabu 2002) and spatial distribution (Hirose and Nakamura 2005) have also been studied using the TRMM $\mathrm{PR}$ in the tropics.

TRMM PR reflectivity values are used to separate the deep and wide convective echoes (Houze et al. 2007; Romatschke et al. 2010; Medina et al. 2010; Romatschke and Houze 2011a). Deep convective echoes are defined as the area of reflectivity higher than $40 \mathrm{dBZ}$ above $10 \mathrm{~km}$, whereas wide intense convective echoes consist of the area of $\mathrm{Ze} \geq 40 \mathrm{dBZ}$ more than $1000 \mathrm{~km}^{2}$ at any altitude. The western Himalayan foothills show small organized convective systems, whereas the eastern Himalayan foothills have a large size of stratiform precipitation (Houze et al. 2007; Romatschke et al. 2010). Romatschke and Houze (2011a) observed that premonsoon rain is more convective in nature, and south Asian regions show similarity in cloud systems during premonsoon and monsoon seasons (Romatschke and Houze 2011b). Saikranthi et al. (2014) investigated the convective and stratiform precipitation characteristics over the Indian subcontinent for different seasons. All the previous studies used the minimum area or contiguous pixels to verify the convective properties of the cloud systems. TRMM PR has a high spatial resolution $(5 \mathrm{~km} \times 5 \mathrm{~km})$, and the present study uses PR reflectivity values to identify the convective properties at high spatial resolution. Investigating $40 \mathrm{dBZ}$ at a very high resolution shows the properties of convective clouds at their individual scale, as the horizontal resolution of PR coincides with the horizontal size of updrafts core (4-5 km, Lucas et al. 1994). The main aim of the present study is to find the regional differences between the most intense convective clouds, their frequency of occurrences and how the vertical profiles differ when they cross the specific altitude (such as 10 and $15 \mathrm{~km}$ ). Which altitudes show the maximum regional differences, such as near the surface or in mixed-phase height or above the troposphere? What are the regional differences in the most intense convective cloud at the east and west side regions of India? Answers to these questions will lead to improvement in the model simulation of intense convective clouds, cumulus parameterizations, satellite rainfall algorithm and lightening probability (Xu and Zipser 2012).
The present work considers different Indian regions. The eastern side consists of the highly convective Bay of Bengal (Rao 1976), and the western side consists of the Western Ghats where orographic lifting promotes a large amount of precipitation (Fig. 1). In the Western Ghats, giant cloud condensation nuclei $(\mathrm{GCCN})$ are found and studies show that the cloud condensation nuclei $(\mathrm{CCN})$ plays an important role in precipitating clouds and cloud systems (Rosenfeld et al. 2008; Rosenfeld et al. 2012). Data and methodology are presented in Sections 2 and 3, respectively, where the concept of most intense convective cell (MICC) is introduced. Results are presented in Section 4 followed by discussion in Section 5. The conclusions are presented in Section 6.

\section{Data}

\subsection{TRMM PR}

The present study uses TRMM-PR 2A25, version-6, attenuation-corrected radar reflectivity factor (i.e. Ze, Iguchi et al. 2000; Masunaga et al. 2002), which is a well-validated parameter (e.g. Iguchi et al. 2000). TRMM is a nonsunsynchronous satellite and samples the area between $38^{\circ} \mathrm{S}$ and $38^{\circ} \mathrm{N}$ several times a day (Kummerow et al. 1998, 2000). TRMM PR works in the Ku band (13.8 GHz) and has a wavelength of $2.2 \mathrm{~cm}$. Horizontal and vertical resolutions of TRMM PR are $\sim 4.3 \mathrm{~km}(\sim 5 \mathrm{~km}$ since August 2001) and $0.25 \mathrm{~km}$, respectively. The sensitivity of TRMM PR is $17 \mathrm{dBZ}$ (18 dBZ since August 2001), and it does not detect the anvil part of MCS (Li and Schumacher 2011). Table 1 shows some characteristics of the TRMM PR. The TRMM PR provides a radar reflectivity factor $(Z e)$ in $\mathrm{dBZ}$ units $\left(\mathrm{dBZ}=10^{*} \log 10 \mathrm{Z}\right)$, where $\mathrm{Z}$ is expressed in $\mathrm{mm}^{6} \mathrm{~m}^{-3}$.

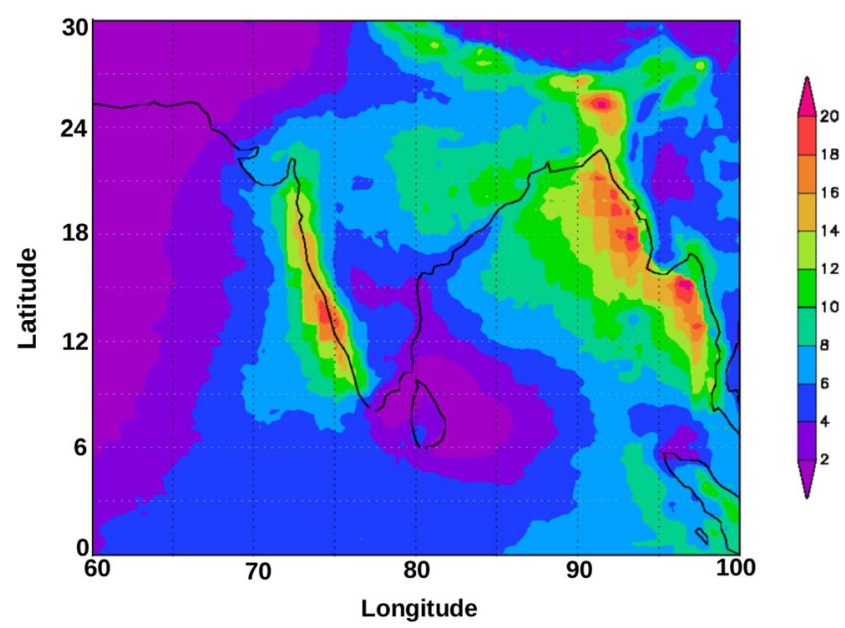

Fig. 1 Daily average rainfall derived from TRMM 3B42 rainfall product for Indian summer monsoon (JJAS) seasons. Unit in colour bar is in $\mathrm{mm} /$ day 
Table 1 Summary of TRMM precipitation radar

\begin{tabular}{ll}
\hline Characteristics & PR specification \\
\hline Frequency & $13.802 \mathrm{GHz}$ \\
Wavelength & $2.2 \mathrm{~cm}$ \\
Pulse Width & $1.6 \mu \mathrm{s}$ \\
Pulse repetition frequency & $2776 \mathrm{~Hz}$ \\
Sensitivity & $\sim 17(18)^{\mathrm{a}} \mathrm{dBZ}$ \\
Swath width & $215(247)^{\mathrm{a}} \mathrm{km}$ \\
Observable range & Earth surface to $19.75 \mathrm{~km}$ (slant angle) \\
Horizontal resolution & $4.3(5.0)^{\mathrm{a}} \mathrm{km}$ \\
Vertical resolution & $0.25 \mathrm{~km}$ at nadir \\
Height & $350(402.5)^{\mathrm{a}} \mathrm{km}$ \\
\hline
\end{tabular}

${ }^{\text {a }}$ Numbers inside the brackets correspond to post TRMM satellite orbit height increase in August 2001

TRMM provides the vertical profile of radar reflectivity in 80 vertical levels, where the zeroth vertical level corresponds to the Earth ellipsoid. At the same time, the TRMM PR contains 49 beams, each separated by $0.71^{\circ}$, and provides total swath width of $247 \mathrm{~km}$. TRMM 2A23 separates the radar echoes into convective and stratiform precipitation based on the vertical profile and horizontal pattern of reflectivity (Awaka et al. 2009). TRMM 2 A23 data is used for the convective rain classification (Awaka et al. 2009) in the present study. TRMM 2A23 algorithm also calculates the cloud echo top height, maximum reflectivity value in the vertical profile, freezing height and width of the bright band.

\subsection{Reanalysis data}

Data from the National Center for Environmental prediction National Center for Atmospheric Research (NCEP-NCAR) is used at a $2.5^{\circ} \times 2.5^{\circ}$ grid (Kalnay et al. 1996) for the column water vapour, temperature and relative humidity profile.

\section{Methods}

\subsection{Reflectivity threshold}

Figure 1 shows the precipitation climatology for JuneSeptember (JJAS) from the TRMM 3B42 daily precipitation data at $0.25^{\circ} \times 0.25^{\circ}$ resolution (Huffman et al. 2007), for 2001 to 2010. The Western Ghats, Bay and Burmese mountains along the coast line of Burma show maximum rainfall. Figure 2 shows the vertical cross section of cloud system observed from the TRMM PR. A narrow region of $\mathrm{Ze} \geq$ $40 \mathrm{dBZ}$ is above the 14-km height and shows the convective cloud crossing $18 \mathrm{~km}$. The horizontal size of the cloud is more than $10 \mathrm{~km}$ and is larger than the size of an updraft core (e.g. $\sim 5 \mathrm{~km}$, Zipser and Lutz 1994). Dixon and Wiener (1993) used

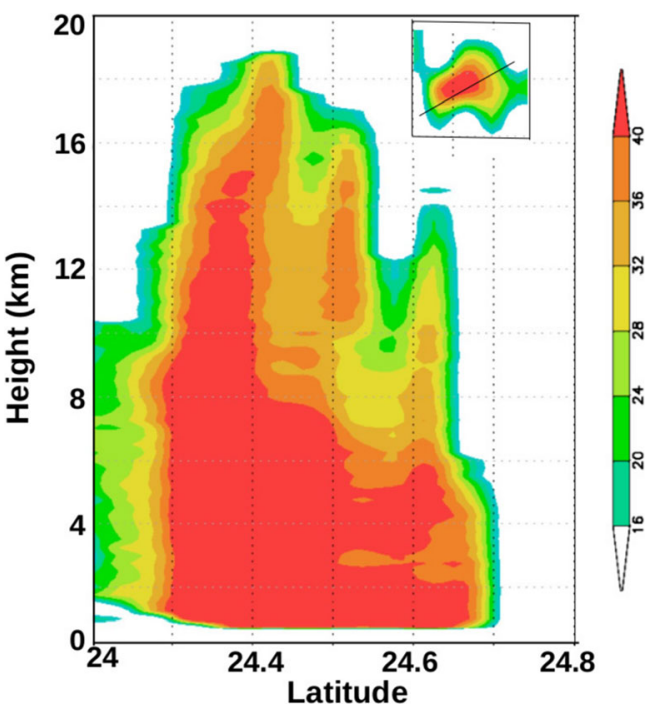

Fig. 2 Vertical section through a MCS seen by TRMM-PR on 3rd June 2003. The inset shows the horizontal section through the cloud system at the $3.25-\mathrm{km}$ height. The ordinate and abscissa are height and latitude $\left({ }^{\circ} \mathrm{N}\right)$, respectively. The colour bar on the right shows $\mathrm{Ze}$ in $\mathrm{dBZ}$ units

the $\mathrm{Ze} \geq 40 \mathrm{dBZ}$ as a proxy for the individual convective cells. Steiner et al. (1995) used the $\mathrm{Ze} \geq 40 \mathrm{dBZ}$ for defining the convective areas in a cloud system. Forty dBZ is used as the proxy for the convective intensity (Zipser et al. 2006; Xu and Zipser 2012) and as a measure of the convective cloud (Houze et al. 2007). Deep and wide intense convective echoes have $\mathrm{Ze} \geq 40 \mathrm{dBZ}$ above a $10-\mathrm{km}$ altitude and are more than $1000 \mathrm{~km}^{2}$ in area (Houze et al. 2007; Romatschke et al. 2010; Romatschke and Houze 2011a, b).

Figure 3 shows the climatology of $\mathrm{Ze} \geq 40 \mathrm{dBZ}$ over India $\left(60^{\circ} \mathrm{E}-100^{\circ} \mathrm{E}\right.$ and $\left.0: 30^{\circ} \mathrm{N}\right)$ within each $1^{\circ} \times 1^{\circ}$ grid box. Figure 3a-1, a-2 shows the frequency (number count) of $\mathrm{Ze} \geq 40 \mathrm{dBZ}$, when $\mathrm{Ze}$ is classified as convective and stratiform pixels, respectively, using TRMM 2A23 data. Numbers show that convective pixels show a higher number with $\mathrm{Ze} \geq$ $40 \mathrm{dBZ}$, but stratiform pixels also show a significant number of $\mathrm{Ze} \geq 40 \mathrm{dBZ}$ ( $\sim 50 \%$ of the convective pixels). The Northeast India and Western Ghats show a higher fraction of convective pixels with $\mathrm{Ze} \geq 40 \mathrm{dBZ}$. The Bay of Bengal and Arabian Sea show different characteristics. The north of Bay shows a higher number of convective pixels with $\mathrm{Ze} \geq 40 \mathrm{dBZ}$, compared to the Arabian sea, where number pixels with $\mathrm{Ze} \geq$ $40 \mathrm{dBZ}$ exist as convective clouds. Figure 3b-1, b-2 shows the average reflectivity with $\mathrm{Ze} \geq 40 \mathrm{dBZ}$ for convective and stratiform pixels in each $1^{\circ} \times 1^{\circ}$ grid box, respectively. Stratiform clouds do not exceed more than $43 \mathrm{dBZ}$ over the Indian subcontinent, and over most of the areas, it is well below $42 \mathrm{dBZ}$. Melting of ice into liquid below freezing level is an essential phenomenon in cloud microphysics and consists of the area of stratiform precipitation. It is important to exclude the strong melting band features from the present study. Figure 4 shows 
Fig. 3 Statistics of $Z e \geq 40 \mathrm{dBZ}$, by using TRMM $2 \mathrm{~A} 23$. a-1 shows the number of convective pixels $(\mathrm{Ze} \geq 40 \mathrm{dBZ})$ in each $1^{\circ} \times$ $1^{\circ}$ grid box. b-1 shows the average of $\mathrm{Ze} \geq 40 \mathrm{dBZ}$ when $\mathrm{Ze}$ is considered as convective pixels using TRMM 2A23 data. a-2, b-2 are similar to $(\mathbf{a}-\mathbf{1}, \mathbf{b}-\mathbf{1})$ but now for the stratiform pixels. Numbers in colour bar are count (a-1, a-2) and dBZ (b-1, b-2)

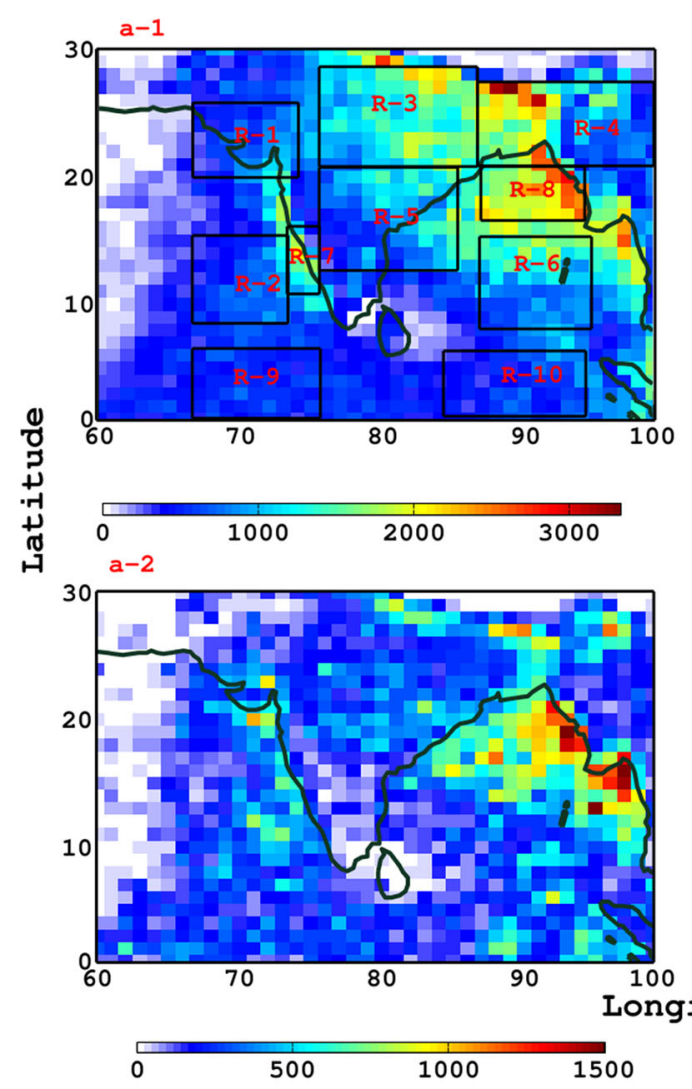

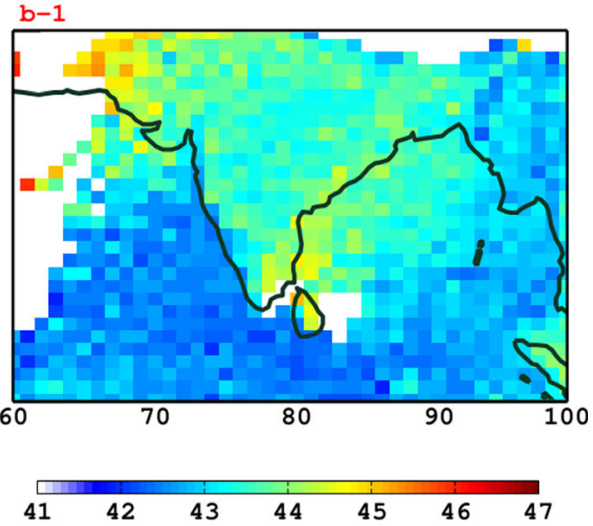

$\mathrm{b}-2$

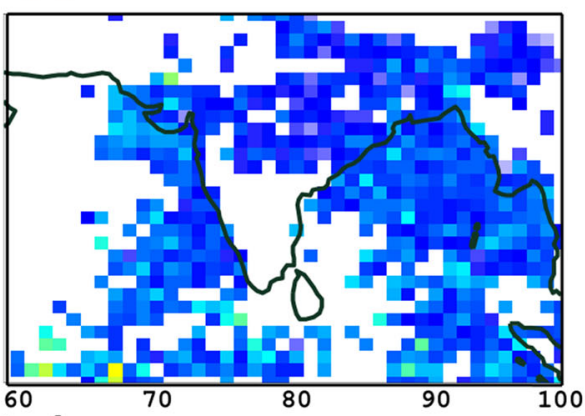

41

4

that less than $10 \%$ of the bright band consists of $\mathrm{Ze} \geq 40 \mathrm{dBZ}$, whereas the Bay has only $5 \%$ of the bright band with $\mathrm{Ze} \geq$ $40 \mathrm{dBZ}$.

\subsection{Definition of subregions}

The selected regions are based on previous studies and on $\mathrm{Ze} \geq$ $40 \mathrm{dBZ}$ statistics. Figure 1 shows the climatology of the spatial distribution of rainfall during JJAS, and Fig. 3 shows the statistics of $\mathrm{Ze} \geq 40 \mathrm{dBZ}$ observed from TRMM PR. Ten

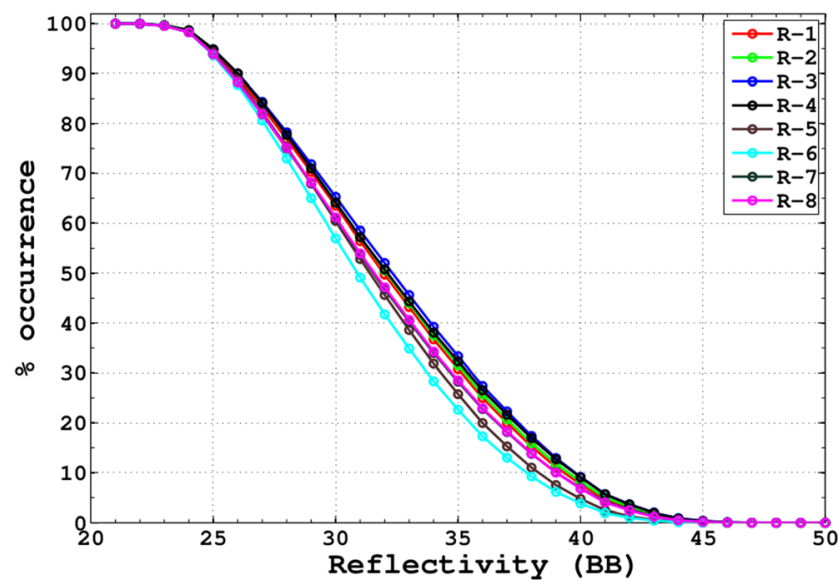

Fig. 4 Intensity of bright band observed from TRMM. Bright bands with $\mathrm{Ze} \geq 40 \mathrm{dBZ}$ are less than $10 \%$ over Indian regions. Over BOB, it is less than $5 \%$ regions are selected for inter-comparison in the vertical structure of convective clouds. R-1 is the area characterized by the midtropospheric cyclones (Miller and Keshavamurthy 1968), whereas areas R-3 and R-4 are part of main monsoon zone. Two boxes are selected in the western regions, one in the Arabian Sea (R-2) and the other around the Western Ghats (R-7). One of the main aims is to understand the difference in the vertical structure of the most intense convective clouds over the Arabian Sea and the Bay. R-6 and R-8 are the regions in the Bay of Bengal that are highly convective (Goswami et al. 2003). The box over the Western Ghats (R-7) is characterized by the orographic lifting which produces heavy precipitation. R-9 and R-10 are the areas in the equatorial oceans.

\subsection{Definition of MICC}

Vertical profile of maximum reflectivity (Ze) within a cloud system is a strong indicator of storm type (e.g. Zipser and Lutz 1994; Xu and Zipser 2012). The life cycle of MCS consists of the growing, mature and decaying stages, and the mature stage has the highest reflectivity values during the life cycle (Williams et al. 1989). Reflectivity values higher than 40 and $35 \mathrm{dBZ}$ at 4.4 and $3.9 \mathrm{~km}$, respectively, were used for defining convective clouds over midlatitude and tropical systems (Zipser and Lutz 1994). Selecting Ze $\geq 40 \mathrm{dBZ}$ as a threshold for convective clouds, based on previous studies, does not look like an appropriate choice, as shown in Figs. 3 
and 4 . The values of $\mathrm{Ze} \geq 40 \mathrm{dBZ}$ also correspond to the melting band (bright band) and stratiform precipitation. Hence, TRMM 2A23 is used to exclude the stratiform clouds from the present analysis. First, the convective pixels from the TRMM 2A23 are selected, and then, MICC is derived. MICC consists of the maximum $\mathrm{Ze}$ value at each altitude within the population of convective clouds, with at least one convective pixel higher than $40 \mathrm{dBZ}$. The lateral size of cloud pixels is equal to the radar horizontal size. It is important that different pixels at all altitude should be connected. Different pixels of MICC correspond to different mature convective cells present at the time of observation. An additional study (not shown) shows that for most of the MICC, $\sim 75-80 \%$ of pixels of each MICC come from the nearest pixels of maximum Ze (i.e. Fig. 2). So, most of the pixels (at different altitude) of each MICC are connected, and MICCs show an important aspect of convective clouds. Also, there are few vertical profiles in which observed reflectivity values are below the PR detection threshold value ( $\sim 17 \mathrm{dBZ})$ at some altitude with higher values at higher altitude. To avoid such cases, only those vertical profiles are considered, where at least four pixels are higher than $17 \mathrm{dBZ}$; the altitude with $\mathrm{Ze}$ is less than $17 \mathrm{dBZ}$. Also, MICCs with less than $1.5-\mathrm{km}$ width are not considered in the present study, which are very shallow clouds. The present study finds the regional differences between the Indian land and surrounding oceans. We also separate the MICCs, whose tops cross the $10 \mathrm{~km}$ (i.e. deep clouds) and $15 \mathrm{~km}$ (near the upper level of tropopause).

\section{Results}

In the region under study (Fig. 3), around $\sim 14,000$ MICCs occurred over the period of 10 years (2001-2010) during June-September. Table 2 shows the number of individual MICCs occurring in the present study over different areas. The Indo-Gangetic plain (R-3 and R-4) exhibits a higher number of MICCs, whereas R-1 has the least number of MICC. The individual vertical profile of MICCs (R-1 and R-4; supplementary figure 1) shows the common features. In the majority of cases, Ze decreases rapidly above $6 \mathrm{~km}$. Some active clouds do not cross the $5-\mathrm{km}$ altitude, whereas some intense convective clouds go beyond the $17 \mathrm{~km}$ altitude (discuss later).

\subsection{Top height distribution}

Figure 5 shows the MICC top height distribution (see the figure caption for definition). Figure 5a shows the frequency of MICC occurrence within each 2-km height interval, and Fig. $5 \mathrm{~b}$ shows the cumulative frequency distribution of the MICC top height. Cloud top height with below $6 \mathrm{~km}$ and above $18 \mathrm{~km}$ shows higher regional differences (Fig. 5).
Table 2 Total number of individual profiles in selected regions for JJAS during last 10 years. Top height distribution of MICC (in \%) at different altitude $(\mathrm{km})$ in different regions

\begin{tabular}{lllll}
\hline Regions & No. of MICC & MICC $\leq 5 \mathrm{~km}$ & MICC $\geq 15 \mathrm{~km}$ & MICC $\geq 18 \mathrm{~km}$ \\
\hline R-1 & 984 & 20.5 & 14.6 & 1.2 \\
R-2 & 1617 & 16.6 & 1.9 & 0.4 \\
R-3 & 2099 & 1.9 & 30.2 & 3 \\
R-4 & 2678 & 1 & 28.6 & 2.1 \\
R-5 & 1580 & 4.8 & 19.2 & 1 \\
R-6 & 1769 & 5.8 & 10.2 & 0.4 \\
R-7 & 1062 & 12.7 & 4 & 0.5 \\
R-8 & 971 & 6.6 & 15.6 & 0.9 \\
R-9 & 506 & 20.3 & 1.8 & 0 \\
R-10 & 732 & 6.9 & 7.7 & 0.3 \\
\hline
\end{tabular}

Land-dominated areas (R-3, R-4 and R-5) show a higher frequency ( $\geq 20-30 \%$; Table 2 ) of MICCs above the $15-\mathrm{km}$ altitude. The western side of India (R-2, R-7 and R-9) has a higher frequency of low-level clouds. Cumulative distribution of MICCs show that nearly $30 \%$ of MICCs are crossing the 15-km altitude over the Indo-Gangetic plain (R-3 and R-4), whereas only $\sim 2 \%$ MICCs are crossing the $15-\mathrm{km}$ altitude over R-2 (Arabian Sea) and R-9 (near equatorial ocean). Nearly $4 \%$ of MICCs are crossing the $15-\mathrm{km}$ altitude over the Western Ghats. Nearly $65 \%$ of MICCs are crossing the $10-\mathrm{km}$ altitude over the Indo-Gangetic plain, whereas only $20 \%$ of MICCs are crossing the $10-\mathrm{km}$ altitude over R-2 (Arabian Sea). Land-originated $\mathrm{CCN}$ and higher convective available potential energy (CAPE) over land delay the precipitation over R-3 and R-4. The western and eastern equatorial Indian Oceans show different characteristics, as the west has a higher fraction (\%) of warm clouds. The overall summary of cloud top height distribution is given in Table 2

\subsection{Average vertical profile}

Figure 6 shows the average vertical profiles of MICCs. The average profile is calculated by using the condition that at least $10 \%$ data points should be at each height, and average is considered for altitudes above $1.5 \mathrm{~km}$ for removing the near ground clutter. This condition is imposed because the number of data points is too little at higher altitudes compared to lower altitudes (supplementary figure 1). The strongest Ze profile is observed in R-3, R-4 (Indo-Gangetic plain) and R-5 (central India), which are mainly land-dominated areas. The highest value of average $\mathrm{Ze}$ corresponds to R-3 (i.e. part of the main monsoon zone on land) at all altitudes, whereas R-2 (Arabian Sea), R-7 (Western Ghats) and R-9 (IOW) show the lowest Ze above and below 10-km altitude. The peaks in Ze occur around the $\sim 2.25-\mathrm{km}$ height over the 

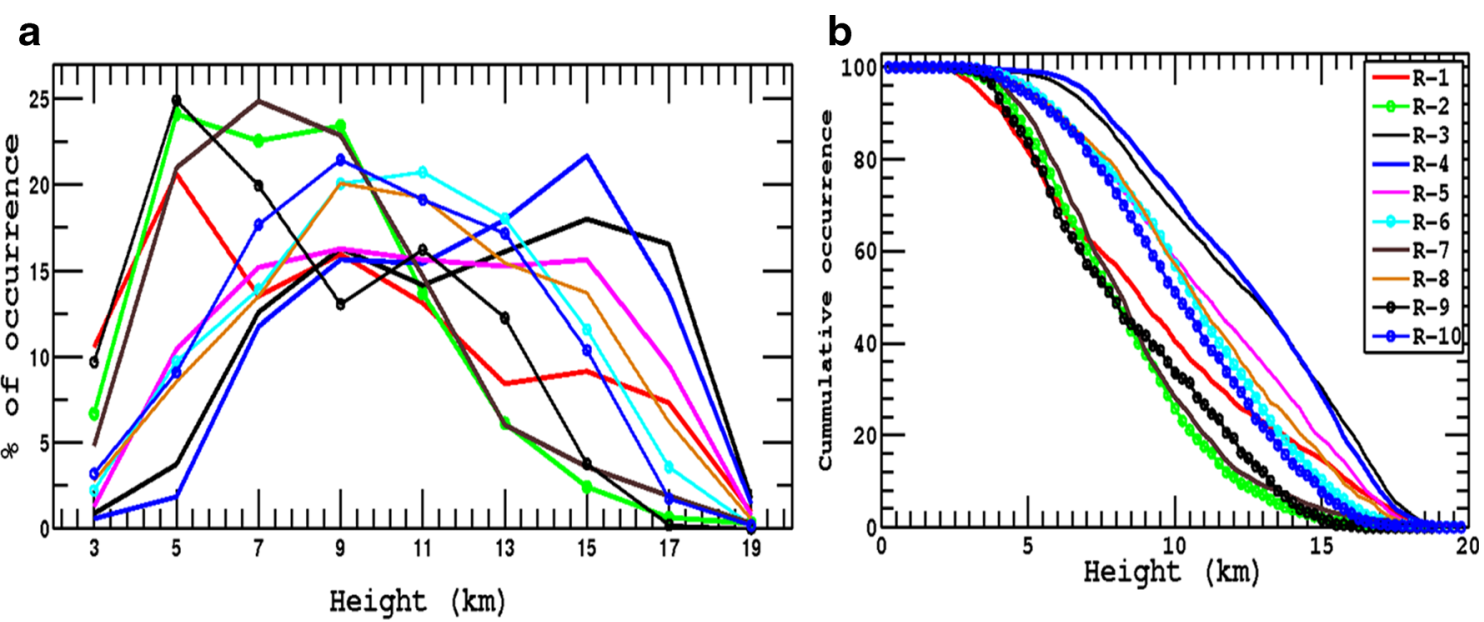

Fig. 5 a Frequency and $\mathbf{b}$ cumulative frequency distribution of cloud top height distribution. The cloud top height is calculated by using the maximum height of $17 \mathrm{dBZ}$. The $x$-axis is height and the frequency is calculated at each 2-km interval, i.e. $3 \mathrm{~km}$ means the MICC lies between 2 and $4 \mathrm{~km}(\mathbf{a})$

Arabian Sea (R-2) and Western Ghats (R-7), and the rate of its decrease is rapid above $3 \mathrm{~km}$, i.e. the decreasing trend begins well below the freezing level (which is about $5-\mathrm{km}$ height; Saikranthi et al. 2013). For land-dominated areas (R-3, R-4 and R-5), the peak occurs around $4.25 \mathrm{~km}$ and then decreases rapidly. Regional differences are more pronounced in the 5- to $12-\mathrm{km}$ altitude range and show the effect of mixed-phase dynamics (Heymsfield et al. 2010; Xu and Zipser 2012). The Ze profile over R-1 matches with

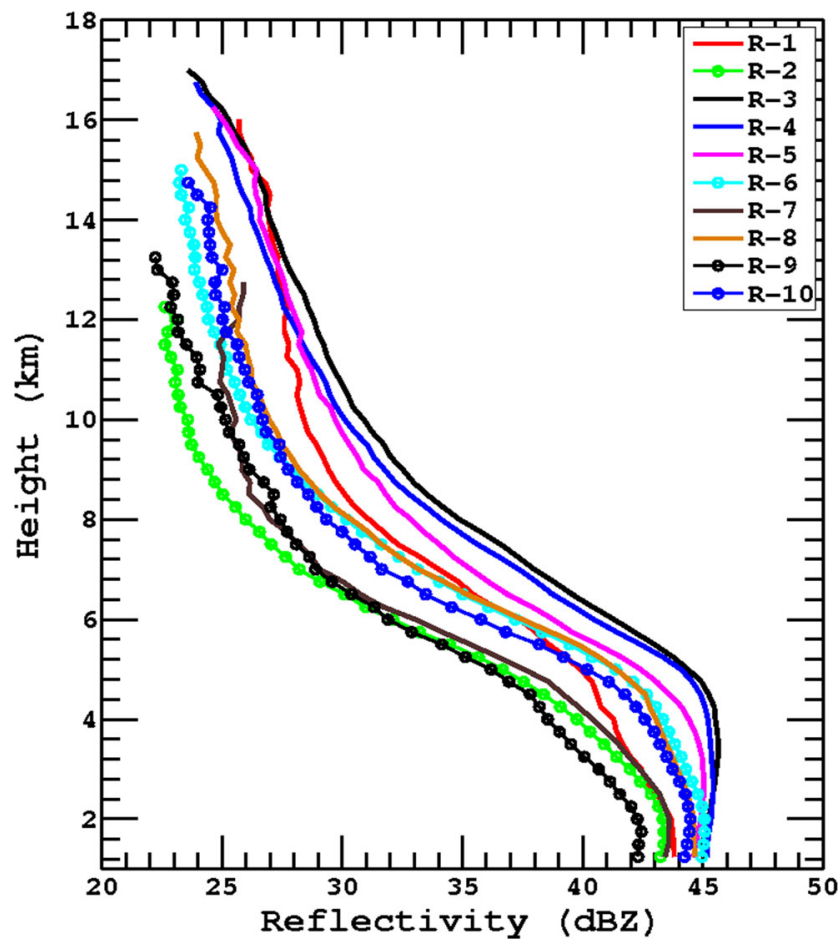

Fig. 6 Average vertical profile for MICC. The average is calculated by considering $90 \%$ of data points at each altitude. Data below $1.5 \mathrm{~km}$ is also removed because of ground clutter that over the Arabian Sea (R-2) and Western Ghats (R-7) below $4 \mathrm{~km}$ and compares with R-3 and R-4 (land areas) above $12 \mathrm{~km}$ and represents the proxy for land and ocean. The least vertical extension occurs over the Arabian Sea (R-2), equatorial ocean (R-9) and Western Ghats (R-7), where the average is well below $14 \mathrm{~km}$, compared to landdominated areas, where the average is crossing the $16-\mathrm{km}$ altitude.

The average vertical profile of MICCs, which are crossing 10 and $15 \mathrm{~km}$, shows the reverse behaviour (Fig. 7) compared to Fig. 6. The Western Ghats (R-7) shows the highest value above the $15-\mathrm{km}$ altitude (Fig. 7b). The Western Ghats (R-7) and central India (R-5) show the strongest vertical profile (contains higher Ze) compared to R-3 and R-4 (Indo-Gangetic plain). Land versus ocean differences vanish for the convective clouds, when they cross the $10-\mathrm{km}$ altitude. This indicates that the mixed-phase height regions are important when considering the vertical structure of the convective clouds (Xu and Zipser 2012). Oceanic regions near the areas (Bay and Arabian Sea) show almost similar patterns (Fig. 7b) compared to Fig. 6. The western equatorial Indian Ocean (R-9) shows the weakest vertical profile. Table 2 shows that the number of MICCs crossing the $15 \mathrm{~km}$ is less, but they are more intense in the Western Ghats (Fig. 7). In all cases, higher regional differences occur between the 5- and 12-km altitudes and lower differences occur below the 4-km altitude.

\subsection{Precipitation structure of MICC}

Figure 8 shows the contour frequency by altitude diagram (CFAD; Yuter and Houze 1995) of MICCs that shows the frequency-altitude dependence. For constructing the CFAD diagram, first the number of occurrences of $\mathrm{Ze}$ in each $1 \mathrm{dBZ}$ interval from 17 to $60 \mathrm{dBZ}$ and at each $0.25 \mathrm{~km}$ (vertical) is 


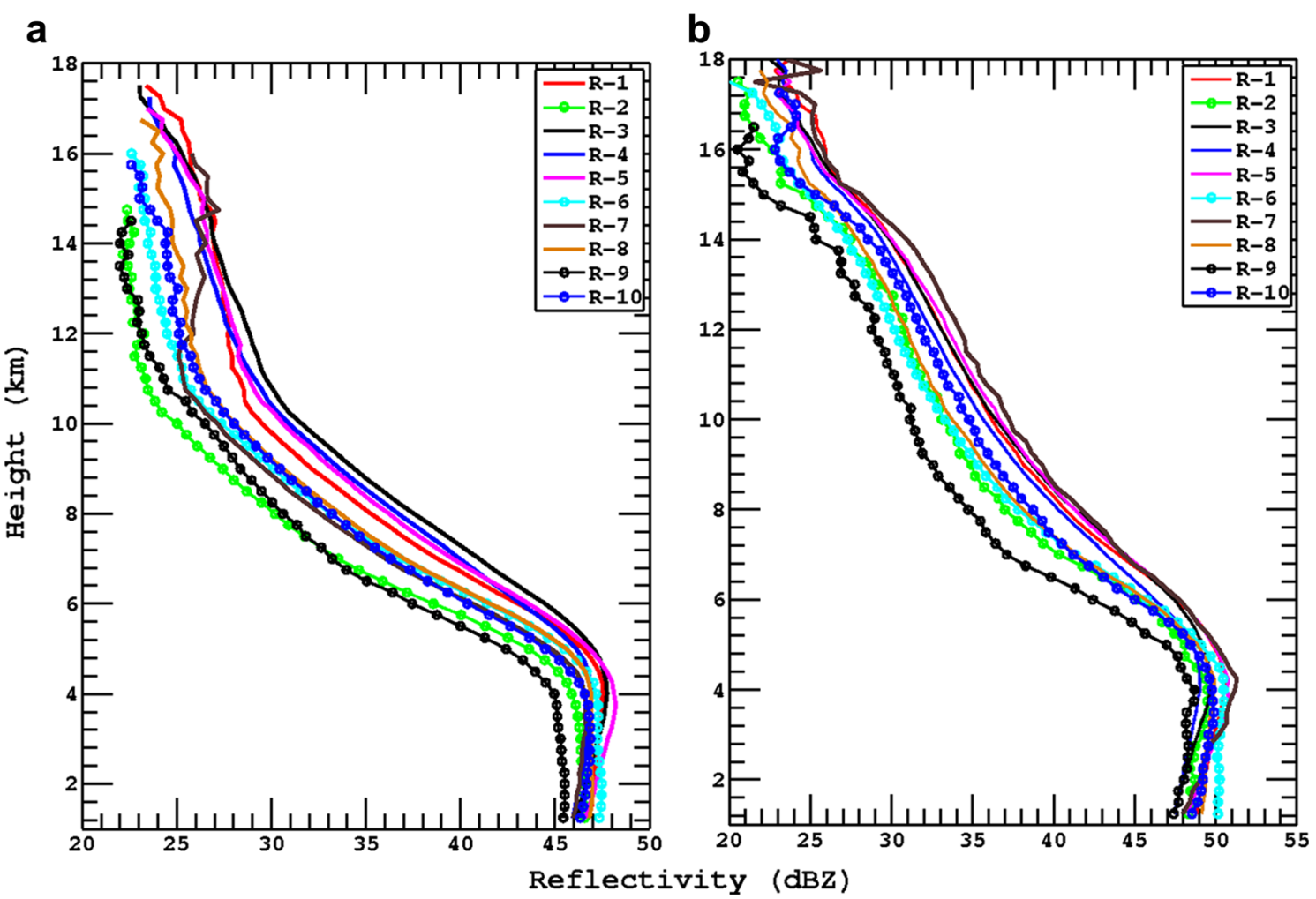

Fig. 7 a, b Average vertical profile of Ze for MICC crossing 10 and $15 \mathrm{~km}$. The average is calculated by considering that at least $90 \%$ of data must contribute at each altitude. Data below $1.5 \mathrm{~km}$ is removed because of ground clutter

calculated. The number of occurrence at each height interval, $f(\mathrm{dBZ}, \mathrm{Hgt})$, is normalized by the fmax (dBZ, Hgt $). f(\mathrm{dBZ}$, $\mathrm{Hgt}) \leq 10$ is eliminated from the entire volume. The CFAD is divided into two regions, below and above $0{ }^{\circ} \mathrm{C}$ (near-freezing level). Below $0{ }^{\circ} \mathrm{C}$, the CFADs are broad and suggest the higher precipitation intensity and are mainly produced by bigger raindrops. Above $0{ }^{\circ} \mathrm{C}$, CFAD shows the lower reflectivity values and indicates weaker precipitation at higher altitude.

Below $5 \mathrm{~km}$, the mode for MICCs occurs around 40$45 \mathrm{dBZ}$ for all the subareas, with different vertical extension. The maxima over the land areas (R-3, R-4, R-5) and Bay (R-6 and R-8) reach up to $5 \mathrm{~km}$, whereas over other subareas, they are just below $3 \mathrm{~km}$. CFAD for MICCs show the decreasing trend of reflectivity between 5 and $8 \mathrm{~km}$. The width of CFAD below $0{ }^{\circ} \mathrm{C}$ shows that convection is intense and higher over land areas compared with oceanic areas. Above $10 \mathrm{~km}$, the higher width in CFAD for land areas shows the substantial variation in $\mathrm{Ze}$. CFAD for the oceanic regions show less width compared to the land-dominated areas, which indicates the weak intense precipitation.

\subsection{Proxy of convective intensity}

Figure 9 shows the maximum height of 30 and $40 \mathrm{dBZ}$ (MH30 and MH40). In the absence of the vertical velocity, MH30 and MH40 are used as the proxy for the convective intensity (Zipser et al. 2006; Xu and Zipser 2012; Bhat and Kumar 2015). The Indo-Gangetic plain (R-3 and R-4) shows the highest fraction ( 25 percentile) of MICC above $8 \mathrm{~km}$ (MH40) altitude, whereas the corresponding value for MH30 is $12 \mathrm{~km}$. The western side (R-1, R-2, R-7 and R-9) shows the least fraction of MH30 and MH40. Fifty percent of MH40 and MH30 are crossing 6.5 and $8.5 \mathrm{~km}$ near the IndoGangetic plain, respectively, whereas the corresponding height over the Western Ghats is 4.5 and $6 \mathrm{~km}$, respectively.

\section{Discussion}

$\mathrm{Ze}$ is a proxy for hydrometeor concentration and its size. Several factors such as strength of low-level convergence, vertical velocity (updraft and downdraft) inside the cloud and horizontal wind shear influence the vertical distribution of hydrometeors. Falling hydrometeors below the freezing level contribute to the precipitation locally and affect the cloud properties. Precipitation formation is a complex process, and several microphysical processes are involved. Microphysical processes are strongly affected by the altitude and phase of hydrometeors.

The difference between R-4 and R- 8 appears to be the classic case of continental versus oceanic clouds (Nesbitt et al. 2000; Toracinta et al. 2002; Liu et al. 2007). In Fig. 6, 

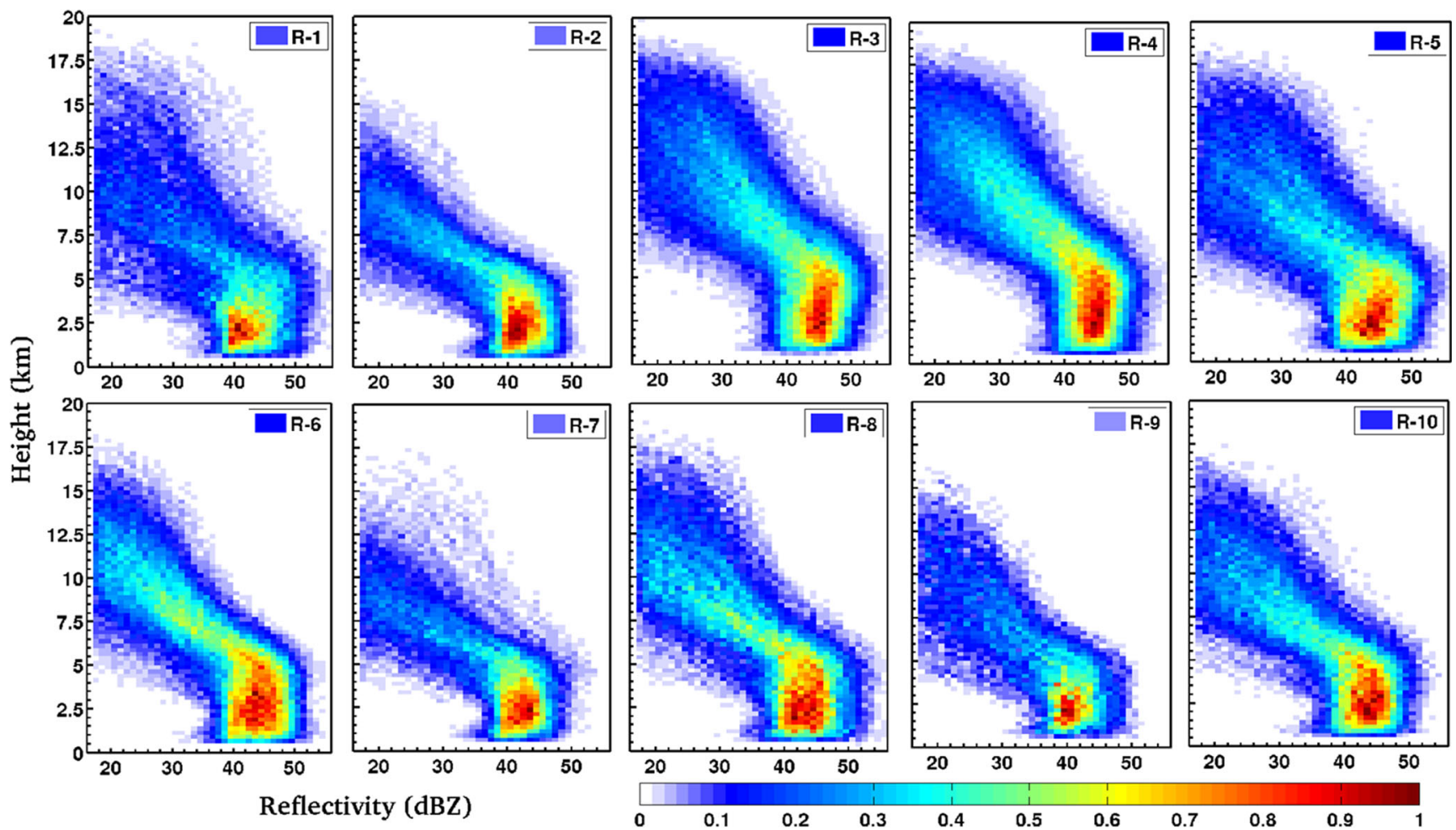

Fig. 8 Contour frequency by altitude diagram (CFAD) for the MICC. Number of occurrence in each reflectivity bin from 18 to $60 \mathrm{dBZ}$ at $1 \mathrm{dBZ}$ and $0.25-\mathrm{km}$ interval is calculated. The image shows the $\%$ of occurrence in each $\mathrm{x}-\mathrm{y}$ bin
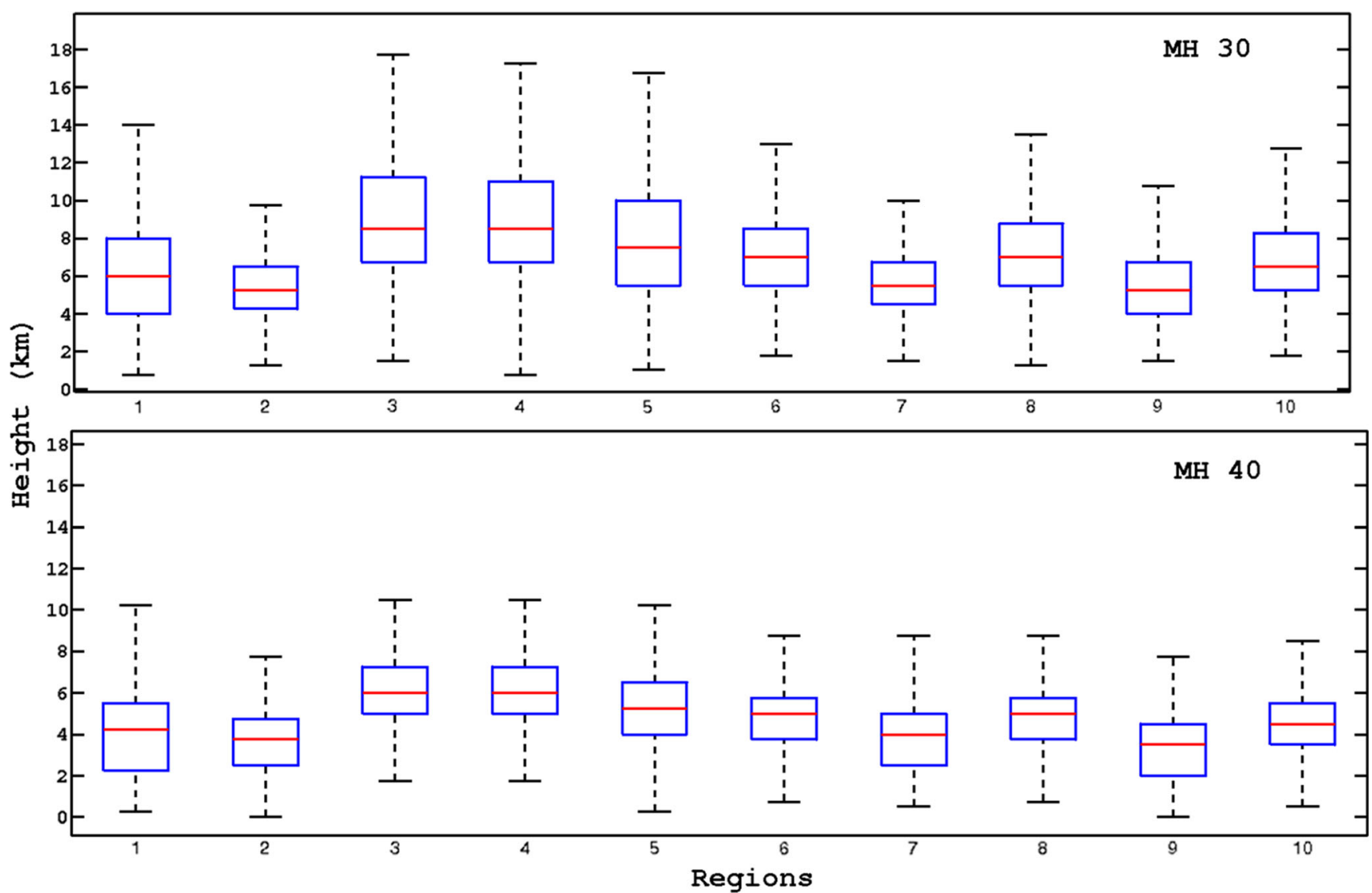

Fig. 9 Maximum height of 40 and $30 \mathrm{dBZ}$. Red colour shows the median value whereas the lower and upper boundary of boxes is showing the 75 and 25 percentiles of maximum height 
Fig. 10 Column water vapour from NCEP data, averaged for 10 years (2001-2010) for the months of JJAS. Unit is in $\mathrm{kg} \mathrm{m}^{-2}$

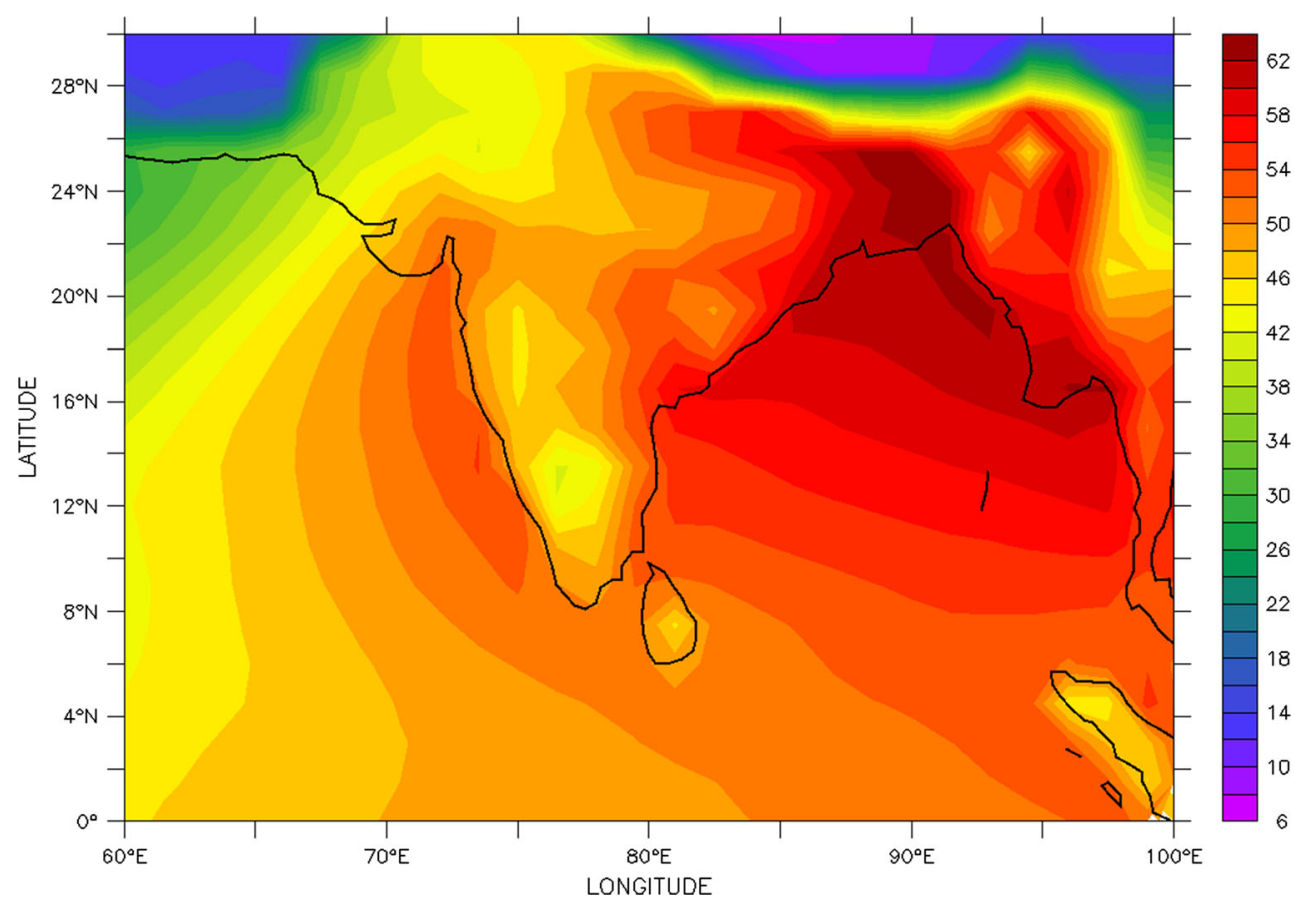

Ze values in R-3 and R-4 areas are nearly $10 \mathrm{dBZ}$ higher compared to that over the Arabian Sea (R-2) and Western Ghats (R-7). Higher differences between 5 and $12 \mathrm{~km}$ (Figs. 6 and 7) reveal that mixed-phase dynamics play an important role in the vertical structure (Heymsfield et al. 2010; Xu and Zipser 2012). Reflectivity (Ze) differences are less, when we consider the $\mathrm{MICC} \geq 10 \mathrm{~km}$ and least for the
MICC $\geq 15 \mathrm{~km}$. The different microphysical processes, such as riming and deposition, depend on the altitude. A small change in the vertical velocity causes the higher differences in reflectivity values within the mixed-phase regions (Heymsfield et al. 2010). Higher reflectivity above the freezing level indicates the strong updraft speed and large ice particles over the land areas (Zipser and Lutz 1994; Zipser et al. 2006). Going
Fig. 11 Surface moist static energy based on NCEP reanalysis data. Unit is in $\mathrm{KJ} \mathrm{kg}^{-1}$

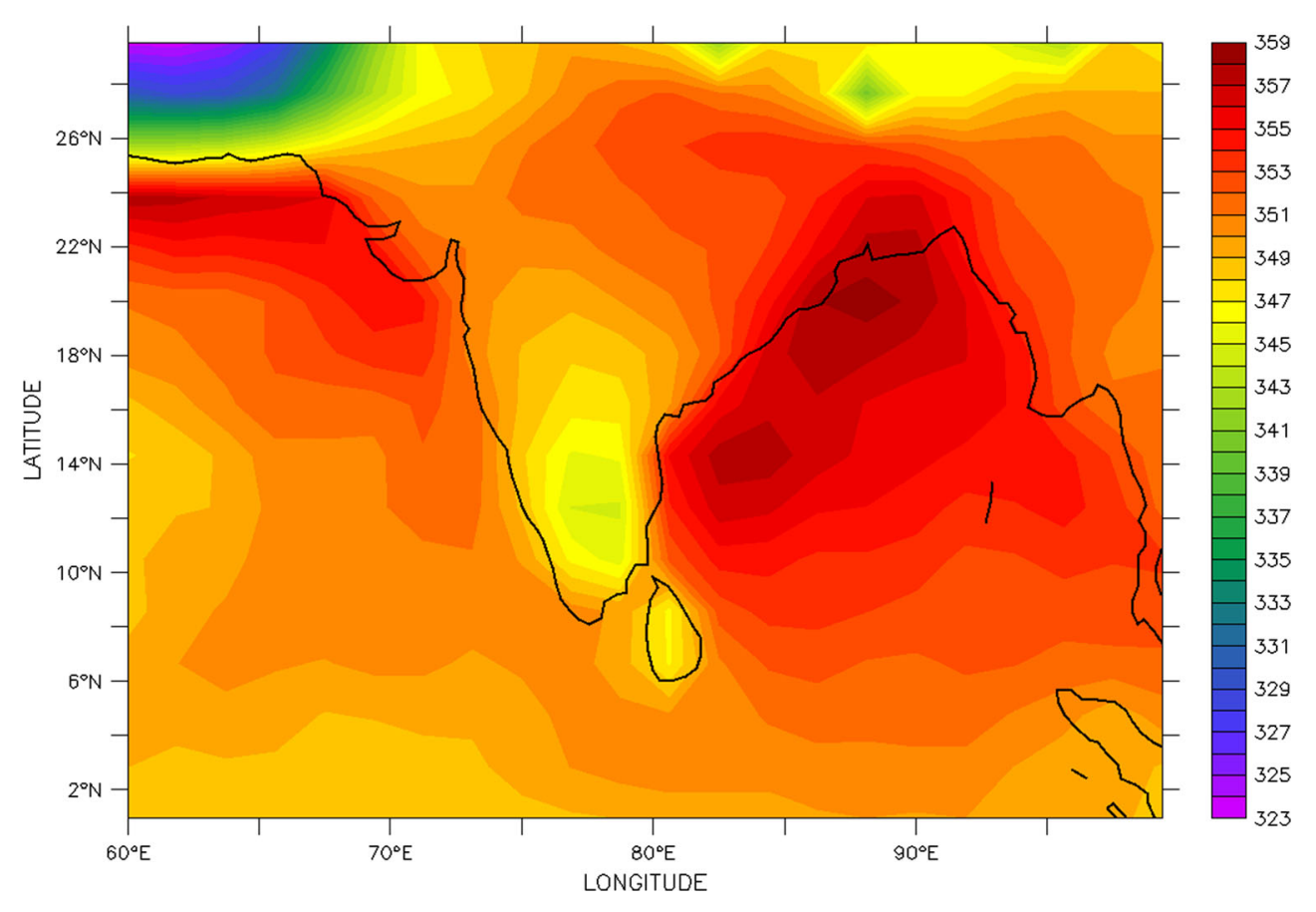


by experience, land areas show stronger updrafts and higher CAPE, which stimulate the large-size hydrometeors at high altitude (Lucas et al. 1994).

Development of a precipitating cloud requires a moist surrounding environment, as precipitating clouds do not develop in dry surrounding air (Sherwood et al. 2004). Moist static energy (MSE) is an important parameter for moist convection, as MSE relates the thermodynamic properties, such as temperature and specific humidity in one equation as $h=\mathrm{Cp} * T+$ $L v * q+g$. $Z$, where $h$ is MSE, Cp is the specific heat of air at constant pressure, $T$ the temperature, $g$ acceleration due to gravity, $Z$ the height above mean sea level, $L$ latent heat of evaporation of water and $q$ the mass of water vapour per unit mass of moist air, i.e. specific humidity. Spatial distribution of column water vapour (Fig. 10), MSE (Fig. 11) and vertical distribution of MSE (Fig. 12) using NCEP data are shown. Due to weak temperature gradients (Sobel and Bretherton 2000) in the tropics, a lower MSE in the midtroposphere points to a drier air. The Bay (R-8) shows the highest MSE at the surface and a relatively more moist midtroposphere (Fig. 11). The western coast of India shows relatively less surface specific humidity and its midtroposphere is also drier. This may partially explain why R-2, R-7 and R-9 show smaller reflectivity values. Land and ocean differences also arise due to the type of CCN and moisture availability (e.g. Rosenfeld et al. 2008). Oceanic regions have a lower concentration of $\mathrm{CCN}$, which is dominated by salt particles

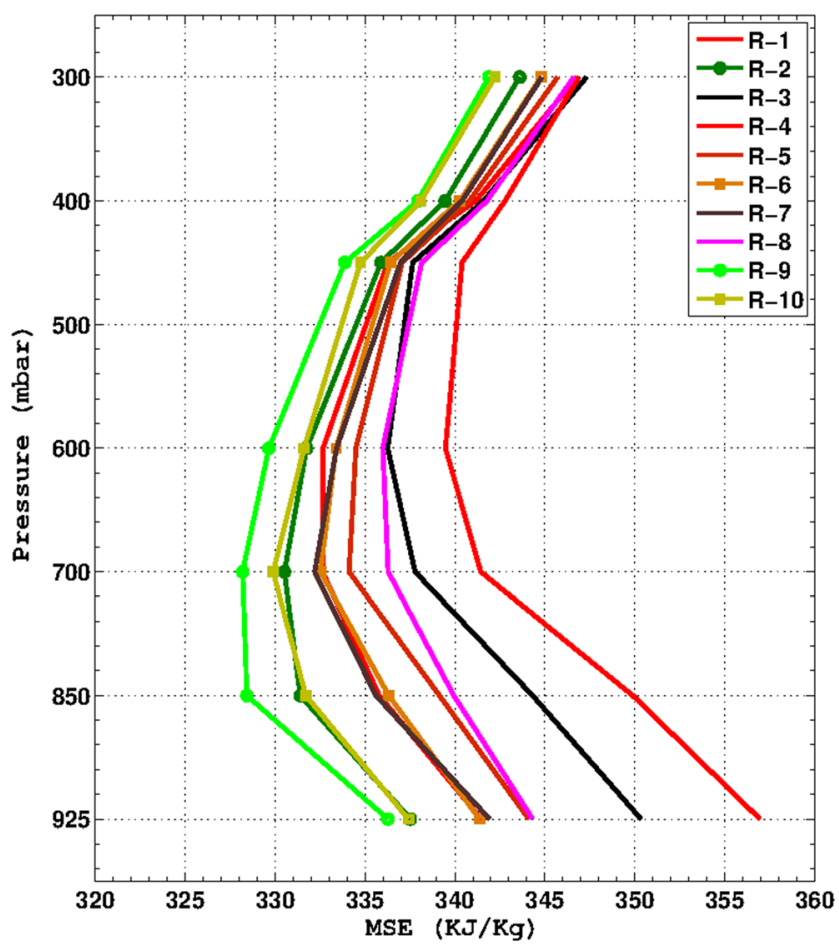

Fig. 12 Vertical profile of moist static energy (MSE) for JJAS months of 2001-2010 based on NCEP data. Unit is in $\mathrm{KJ} \mathrm{kg}^{-1}$
(Pruppacher and Klett 1997), that favours the warm rain processes and leaves fewer hydrometeors to carry at higher altitude (Konwar et al. 2012). Over land, precipitation is delayed due to a higher concentration of CCN (Rosenfeld et al. 2008; Konwar et al. 2012), and more water is carried to higher levels (e.g. Wang 2005).

The average vertical profile and cloud top height distribution over the Arabian Sea (AS; R-2) and Bay of Bengal (BOB; R-6) show how different surface and atmospheric conditions (horizontal pattern and vertical profile of MSE, water vapour) influence the cloud properties. Below the freezing level, number of MICCs are higher (i.e. $~ 16 \%$ ) over R-2 compared to R$6(\sim 5.8 \%)$. The difference in MSE (Figs. 11 and 12) over AS and BOB is because of the difference in $q$, as SST does not show much difference. The Arabian Sea is more saline, and the $\mathrm{CCN}$ over AS is dominated by salt particles. Over the Arabian Sea, giant CCNs favour early precipitation formation by the collision-coalescence mechanism (Konwar et al. 2012). As a result, condensed water is removed nearer to the cloud base in Arabian Sea clouds compared to Bay clouds.

\section{Conclusions}

The objective of the present paper is to understand reflectivity distribution in the most intense convective clouds and regional differences between the east and west coast of India. Understanding vertical structure of reflectivity is important as it reflects the distribution of the hydrometeors within the convective clouds. The most intense convective cell is constructed from the population of convective clouds for ten distinct areas over the Indian region by using TRMM 2A23 and $2 \mathrm{~A} 25$ data. The following are the major conclusions of the study:

1. The differences in the vertical profile are higher between 5- and 12-km altitudes, and land cells are more intense as compared to ocean cells. Land versus ocean separations becomes less in deep convective clouds (i.e. MICCs are crossing $10 \mathrm{~km}$ ) and least when MICCs are crossing the $15-\mathrm{km}$ altitude. The regional differences in Ze depend on the cloud top height of MICC.

2. On an average, clouds over the Indo-Gangetic plain are more intense (shows higher reflectivity values), whereas the Arabian Sea and Indian Ocean near the equator (west side) have the weakest convective clouds. The Western Ghats has less fraction of MICC $(>15 \mathrm{~km})$, but they are the most intense clouds.

3. West versus east differences in Ze and cloud top height are clear, and average vertical profiles are stronger (high Ze) near the eastern coast/side compared to the western coast/ side and have a higher fraction of high-level clouds. 


\section{References}

Alcala C, Dessler A (2002) Observations of deep convection in the tropics using the tropical rainfall measuring mission (TRMM) precipitation radar. J Geophys Res 107:D244792. doi:10.1029/ 2002JD002457

Awaka J, Iguchi T, Okomoto K (2009) TRMM PR standard algorithm 2A23 and its performance on bright band detection. J Meteorol Soc Jpn 87A:31-52

Bhat GS, Kumar S (2015) Vertical structure of cumulonimbus towers and intense convective clouds over the South Asian region during the summer monsoon season. J Geophys Res Atmos. doi:10.1002/ 2014JD022552

Charney JG (1969) A further note on large-scale motions in the tropics. J Atmos Sci 26:182-185

Dixon M, Wiener G (1993) TITAN: thunderstorm identification, tracking, analysis, and nowcasting a radar-based methodology. J Atmos Oceanic Tech 10:785-797

Goswami BN, Ajayamohan R, Xavier PK, Sengupta D (2003) Clustering of synoptic activity by Indian summer monsoon intraseasonal oscillations. Geophys Res Lett 30:141-144. doi:10.1029/ 2002GL016734

Heymsfield GM, Tian L, Heymsfield AJ, Li L, Guimond S (2010) Characteristics of deep tropical and subtropical convection from nadir-viewing high-altitude airborne Doppler radar. J Atmos Sci 67:285-308

Hirose K, Nakamura K (2005) Spatial and diurnal variation of precipitation systems over Asia observed by the TRMM precipitation radar. J Geophys Res 110: doi:10.1029/2004JD004815

Holton JR (2004) An introduction to dynamic meteorology, Chapter 11; 4th Edition. Elsevier Academic Press, New York, pp 531

Houze RA Jr (1989) Observed structure of mesoscale convective systerm and implications for large-scale heating. Q J Roy Meteorol Soc 115: 425-461

Houze RA Jr, Wilton DC, Smull FB (2007) Monsoon convection in the Himalayan region as seen by the TRMM precipitation radar. Q J Roy Meteorol Soc 133:1389-1411

Huffman GJ, Coauthors (2007) The TRMM Multisatellite Precipitation Analysis (TMPA): Quasi- Global, Multilayear, Combined-sensor Precipitation Estimates at Fine Scales. J Hydrometeor 8:38-55

Iguchi T, Kozu T, Meneghini R, Awaka J, Okamoto K (2000) Rainprofiling algorithm for the TRMM precipitation radar. J Appl Meteorol 39:2038-2052

Kalnay E et al (1996) The NCEP/NCAR 40 year reanalysis project. Bull Am Meteorol Soc 77:437-470

Konwar M, Maheskumar RS, Kulkarni JR, Freud E, Goswami BN, Rosenfeld D (2012) Aerosol control on depth of warm rain in convective clouds. J Geophys Res 117: doi:10.1029/2012JD017585

Kummerow C, Barnes W, Kozu T, Shiue J, Simpson J (1998) The tropical rainfall measuring mission (TRMM) sensor package. J Atmos Oceanic Tech 15:809-817

Kummerow C, Simpson J, Thiele O, Barnes W, Chang ATC, Stocker E, Adler RF, Hou A, Kakar R, Wentz F, Ashcroft P, Kozu T, Hong Y, Okamoto K, Iguchi T, Kuroiwa H, Im E, Haddad Z, Huffman G, Ferrier B, Olson WS, Zipser E, Smith EA, Wilheit TT, North G, Krishnamurti T, Nakamura (2000) The status of the tropical rainfall measuring mission (TRMM) after two years in orbit. J Appl Meteorol 39:1965-1982

Li W, Schumacher C (2011) Thick anvils as viewed by the TRMM precipitation radar. J Climate 24:1718-1735

Liu C, Zipser ED, Nesbitt SW (2007) Global distribution of tropical deep convection: different perspectives from TRMM infrared and radar data. J Climate 20:489-503
Liu C, Zipser ED, Cecil SW, Nesbitt SW, Sherwood S (2008) A cloud and precipitation feature database from nine years of TRMM observations. J Appl Meteorol Climatol 47(10):2712-2728

Liu C, Cecil DJ, Zipser EJ, Kronfeld K, Robertson R (2012) Relationships between lightning flash rates and radar reflectivity vertical structures in thunderstorms over the tropics and subtropics. J Geophys Res 117: D06212. doi:10.1029/2011JD017123

Lucas C, Zipser EJ, LeMone MA (1994) Vertical velocity in oceanic convection off tropical Australia. J Atmos Sci 51:3183-3193

Masunaga H, Iguchi T, Oki R, Kachi M (2002) Comparison of rainfall products derived from TRMM microwave imager and precipitation radar. J Appl Meteorol 41:849-862

Medina S, Houze RA Jr, Kumar A, Niyogi D (2010) Summer monsoon convection in the Himalayan region: terrain and land cover effects. Quart J Roy Meteor Soc 136:593-616

Miller FR, Keshavamurthy RN (1968) Structure of an Arabian sea summer monsoon system. East West Center Press, Honolulu

Nesbitt SW, Zipser E, Cecil C (2000) A census of precipitation features in the tropics using TRMM radar, ice scattering, and lightning observations. J Climate 13:4087-4106

Nesbitt SW, Cifelli R, Rutledge A (2006) Storm morphology and rainfall characteristics of TRMM precipitation features. Mon Weather Rev 134:2702-2721

Pruppacher HR, Klett JD (1997) Microphysics of clouds and precipitation. Kluwer Academic Publishers, Dordrecht, p 961

Rao YP (1976) Southwest monsoon. India Meteorological Department. http://www.imd.gov.in/section/nhac/dynamic/Monsoon_frame.html

Riehl H (1979) Climate and weather in the tropics. Academic Press, London, p 611

Romatschke U, Houze RA Jr (2011a) Characteristics of precipitating convective systems in the premonsoon season of South Asia. J Hydrometeorol 12:3-26. doi:10.1175/2010JHM1289

Romatschke U, Houze RA Jr (2011b) Characteristics of precipitating convective systems in the South Asian Monsoon. J Hydrometeorol 12:157-180. doi:10.1175/2010JHM1311.1

Romatschke U, Medina S, Houze RA Jr (2010) Regional, seasonal, and diurnal variations of extreme convection in South Asian region. J Climate 23:419-439

Rosenfeld D, Lohmann U, Raga GB, O'Dowd CD, Kulmala M, Fuzzi S, Reissell A, Andreae MO (2008) Flood or drought: how do aerosols affect precipitation? Science 321:1309-1313

Rosenfeld D, William LW, Khain A, Cotton WR, Carrio G, Ginis I, Golden JH (2012) Aerosol effects on microstructure and intensity of tropical cyclones. Bull Am Meteorol Soc 93:987-1001

Saikranthi K, Narayana TN, Radhakrishna B, Rao SVB (2013) Impact of misrepresentation of freezing-level height by the TRMM Algorithm on shallow rain statistics over India and adjoining oceans. J Appl Metroe Clim 52: 2001:2008

Saikranthi K, Narayana TN, Radhakrishna B, RAO SVB (2014) Morphology of the vertical structure of precipitation over India and adjoining oceans based on long-term measurements of TRMM PR. Geophys Res Atmos 119:8433-8449. doi:10.1002/ 2014JD021774

Sherwood SC, Minnis P, McGill M (2004) Deep convective cloud-top heights and their thermodynamic control during crystal-face. J Geophys Res 109: doi:10.1029/2004JD004811

Simpson J, Kummerow C, Tao W, Adler R (1998) Eyeing the eye: exciting early stage science results from TRMM. Bull Am Meteorol Soc 79:1711-1711

Sobel A, Bretherton CS (2000) Modeling tropical precipitation in a single column. J Climate 13:4378-4392

Steiner M, Houze RA, Yuter SE (1995) Climatological characterization of three-dimensional storm structure from operational radar and rain gauge data. J Appl Meteorol 34:1978-2007 
Takayabu YN (2002) Spectral representation of rain profile and diurnal variations observed with TRMM PR over the equatorial area. Geophys Res Lett 29: doi:10.1029/2001GL014113

Toracinta E, Cecil D, Zipser E, Nesbitt S (2002) Radar, passive microwave, and lightning characteristics of precipitating systems in the tropics. Mon Weather Rev 130:802-824. doi:10.1175/1520-0493

Wang C (2005) A modeling study of the response of tropical deep convection to the increase of cloud condensation nuclei concentration: 1. Dynamics and microphysics. J Geophys Res 110: doi:10.1029/ 2004JD005720

Williams ER, Weber ME, Orville RE (1989) The relationship between lighting type and convective state of thunderstorms. J Geophys Res 94:13213-13220
$\mathrm{Xu}$ W, Zipser EJ (2012) Properties of deep convection in tropical continental, monsoon, and oceanic rainfall regimes. Geophys Res Lett 39: doi:10.1029/2012GL051242

Yuter SE, Houze RA Jr (1995) Three-dimensional kinematic and microphysical evolution of Florida cumulonimbus. Part II: frequency distribution of vertical velocity, reflectivity, and differential reflectivity. Mon Weather Rev 123:1941-1963

Zipser EJ, Lutz K (1994) The vertical profile of radar reflectivity of convective cells a strong indicator of storm intensity and lightning probability. Mon Weather Rev 122:1751-1759

Zipser EJ, Cecil DJ, Liu C, Nesbitt SW, Yorty DP (2006) Where are the most intense thunderstorms on Earth? Bull Am Meteorol Soc 87: 1057-1071 